\title{
The Coastline Evolution Model 2D (CEM2D) V1.1
}

\author{
Chloe Leach $^{1}$, Tom Coulthard ${ }^{2}$, Andrew Barkwith ${ }^{3}$, Daniel R. Parsons ${ }^{2}$, and Susan Manson ${ }^{4}$ \\ ${ }^{1}$ School of Geography, The University of Melbourne, Parkville, Melbourne, VIC 3010, Australia \\ ${ }^{2}$ Department of Geography, Geology and Environmental Science, University of Hull, Hull, HU6 7RX, UK \\ ${ }^{3}$ British Geological Survey, Environmental Science Centre, Keyworth, Nottingham, NG12 5GG, UK \\ ${ }^{4}$ Environment Agency, Crosskill House, Mill Lane, Beverley, HU17 9JW, UK
}

Correspondence: Chloe Leach (chloe.leach@unimelb.edu.au)

Received: 22 July 2019 - Discussion started: 9 September 2019

Revised: 15 January 2021 - Accepted: 22 July 2021 - Published: 7 September 2021

\begin{abstract}
Coasts are among the most intensely used environments on the planet, but they also present dynamic and unique hazards, including flooding and erosion. Sea level rise and changing wave climates will alter patterns of erosion and deposition, but some existing coastline evolution models are unable to simulate these effects due to their one-dimensional representation of the systems or the sediment transport processes. In this paper, the development and application of the Coastline Evolution Model 2D (CEM2D) are presented, a model which incorporates these influences. The model has been developed from the established CEM and is capable of simulating fundamental cause-effect relationships in coastal systems. The two-dimensional storage and transport of sediment in CEM2D, which are only done in one-dimension in CEM, mean it is also capable of exploring the influence of a variable water level on sediment transport and the formation and evolution of morphological features and landforms at the mesoscale. The model sits between one-dimensional and three-dimensional models, with the advantage of increased complexity and detail in model outputs compared to the former but with more efficiency and less computational expense than the latter.
\end{abstract}

\section{Introduction}

Coastal systems are amongst the most dynamic environments on the planet, with their form and evolution being highly sensitive to changes in environmental conditions over a range of spatial and temporal scales (Wong et al., 2014). Under the context of rising global sea levels and considering the social and economic importance of many coastal locations, un- derstanding the behaviour and potential future evolution of coastal environments is essential for the development of suitable and sustainable management (Wong et al., 2014). Numerical models are increasingly being used for this purpose, providing powerful tools that can give an insight into the complex morphodynamics and sensitivities of coastal systems (e.g. Ashton et al., 2001; Nam et al., 2009; Nicholls et al., 2012).

Simulating changes in coastal geomorphology up to millennial timescales and up to hundreds of kilometres, herein referred to as the mesoscale, is highly relevant for coastal management and also fits with our historic frame of observation for model validation and calibration (French et al., 2015; van Maanen et al., 2016). This scale sits between reduced complexity reductionist studies and complex synthesist investigations, which have more traditionally been the focus of research into coastal behaviours (Fig. 1) (van Maanen et al., 2016).

Reductionist or "bottom-up" models are designed to investigate small-scale processes that act over relatively short timescales (Fig. 1) (van Maanen et al., 2016). They typically simulate complex behaviours by including a large range of processes that could influence the evolution of the system using more detailed calculations at higher resolutions (van Maanen et al., 2016). Using these types of models for mesoscale applications would be computationally expensive and inefficient, since there are a large number of processes that could be simulated over relatively long timescales (van Maanen et al., 2016). Decisions would have to be made about which processes to include, since each process adds computational expense and additional uncertainty, which can propagate errors or inaccuracies over long simulated timescales 


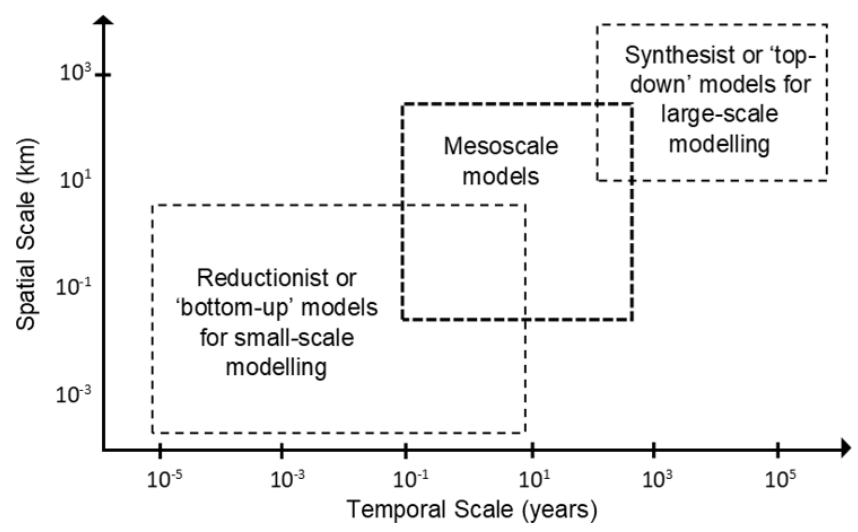

Figure 1. Spatial and temporal ranges for traditionally reductionist and synthesist models, with mesoscale models highlighted in grey within the scale appropriate for coastal management (adapted from Gelfenbaum and Kaminsky, 2010; van Maanen et al., 2016).

(Hutton, 2012; Murray, 2007). Mesoscale models, like many types of model, should be parsimonious and include only fundamental processes that capture the main physical dynamics of a system, thus minimising model uncertainty (Wainwright and Mulligan, 2013).

Synthesist or "top-down" models are designed to simulate large-scale behaviours that act over longer time periods and often include only a few parameterised processes (Fig. 1) (Murray, 2007; van Maanen et al., 2016). They are intended to represent general behaviours and patterns in natural systems, rather than pertaining to spatially explicit research questions (Murray, 2007). As such, synthesist models are relatively limited in their ability to provide a level of understanding and prediction of coastal behaviours that is required for mesoscale research (Murray, 2007).

In the field of coastal modelling, there is a gap for a two-dimensional coastal model that can simulate features such as spits, bars, and beach migration, along with a dynamic nearshore bathymetry and a variable water level, but that is parsimonious enough to enable short run times, allowing us to answer research questions about coastal evolution at meso-spatiotemporal scales. Existing models with such scope, such as the Coastline Evolution Model (CEM), COVE, and GENESIS (Hanson and Kraus, 1989; Ashton et al., 2001; Hurst et al., 2014), are limited to transporting sediment in one dimension and represent the coastline simply as a line with little accommodation for the nearshore shape or bathymetry. This means that the models are parsimonious and fast but are limited in their application, for example, to investigate the effects of sea level rise on coastal geomorphology. Hybrid shoreline change models such as COCOONED (Antolínez et al., 2019) and CoSMoS-COAST (Vitousek et al., 2017) calculate sediment transport in crossshore and alongshore directions and can vary the water level in the model but are transect based and do not include a dynamically evolving bathymetry. The LX-Shore model (Robi- net et al., 2018) is cellular based, with alongshore and crossshore sediment transport calculations but has an equilibrium beach profile as in models such as CEM and COVE. In contrast to these longer-term models, finer-scale models such as Delft3D (Lesser et al., 2004) can simulate coastal hydrodynamics and sediment transport processes in two- or threedimensions, but their complexity and long model run times mean that investigating sea level rise responses over mesotimescales is presently impracticable.

In this paper, the development and application of the Coastline Evolution Model 2D (CEM2D) is presented. This model is based on the underlying assumptions of the CEM but with sediment transport processes that are applied over the two-dimensional grid, which allows us to represent the morphology of coastlines in more detail and incorporate sea level rise. A key aim of the model development is to create a tool to improve our understanding of the mesoscale morphodynamic behaviour of coastal systems, their sensitivities, and the influence that sea level rise may have on their evolution over centennial to millennial timescales. We describe the model's operation and parameterisation in full and compare the model outputs to the original CEM, illustrating some similarities in model outputs but also key differences that are due to the improved two-dimensional representation of the coastline and sediment transport processes. Validation of exploratory models like CEM2D is limited, particularly in this case, where there is a lack of data showing the evolution of coastal systems under changing wave patterns and water levels over such long time periods. CEM2D's performance is therefore here evaluated against "standard" CEM simulation results from varying wave climates and directions.

\section{The Coastline Evolution Model (CEM)}

As CEM2D builds on many concepts developed in the original CEM, it is important to first understand how CEM operates. CEM is grid based, dividing a plan-view coastline into a grid of regular square cells of a user-defined size $(\mathrm{m})$. Each of these cells contains a fractional proportion of sediment $\left(F_{i}\right)$ that represent its horizontal fill across the domain. The $F_{i}$ values are updated according to the alongshore transport of sediment and the landward or seaward migration of the shore (Ashton et al., 2001). Cells can be defined as fast- or sloweroding cells to represent basic lithological characteristics of a coastline.

The one-line coastline can be drawn along shoreline cells at the interface between land and sea cells. A shoreline search technique is used to locate these shoreline cells. The initial shoreline cell on the left side of the domain is located by iterating through the first column of cells from the top down until a land cell is found. A clockwise search is then used around the first shoreline cell to locate the next cell. This is then repeated until all shoreline cells are found. The angle of the deep-water wave crest and local shoreline orientation 


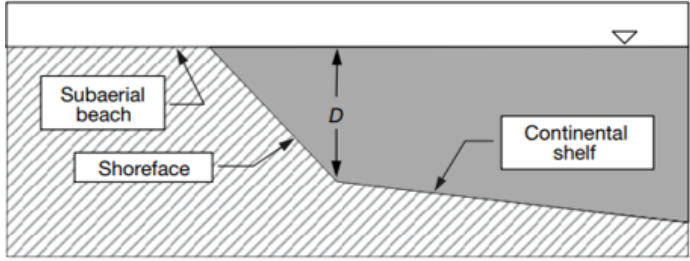

Figure 2. Cross-sectional profile of CEM showing the location of the depth of closure, where the shoreface slope intersects the continental shelf slope (following Ashton et al., 2001).

determines the direction of sediment transport between cells. If the local relative wave angle is less (greater) than the angle that maximises sediment transport, sediment flux is calculated using a central (upwind) finite-difference technique (Ashton et al., 2001; Ashton and Murray, 2006a).

The sediment flux and net erosion or accretion of material in each cell determines the cross-shore movement of the shoreline and is controlled by wave-induced sediment transport calculated using the CERC formula in terms of breaking wave quantities following Eq. (1):

$Q_{\mathrm{s}}=K H_{\mathrm{b}}^{\frac{5}{2}} \sin \left(\phi_{\mathrm{b}}-\theta\right) \cos \left(\phi_{\mathrm{b}}-\theta\right)$,

where $Q_{\mathrm{s}}$ is the sediment flux $\left(\mathrm{m}^{3} \mathrm{~d}^{-1}\right), K$ is a calibration coefficient, $H_{\mathrm{b}}$ is the breaking wave height $(\mathrm{m}), \phi_{\mathrm{b}}$ is the breaking wave angle $\left({ }^{\circ}\right)$, and $\theta$ is the local shoreline orientation $\left({ }^{\circ}\right)$. Breaking wave characteristics are calculated from an offshore wave climate that is transformed over assumed shore-parallel contours using linear wave theory (Ashton et al., 2001). An arbitrary offshore water depth is iteratively reduced, and the offshore wave angle and height are recalculated until the waves break. The wave climate characteristics at the point of breaking are then used to compute the sediment flux between each cell and the net erosion or deposition of sediment using Eq. (2) (Ashton et al., 2001):

$\Delta F_{i}=Q_{\mathrm{s}, \text { net }} \Delta t /\left(W^{2} D_{i}\right)$,

where $W$ is the cell width and $D_{i}$ the depth to which significant sediment transport occurs, known as the depth of closure (DoC). The DoC is defined as the location from the shore where the depth of water is greater than the depth of wave influence and thus the flow has a negligible impact on crossshore sediment transport; this depth is often approximated as half the average wavelength (Hallermeier, 1978; Nicholls et al., 1997; Pinet, 2011). The assumed location of the DoC in CEM is the point where the continental shelf and the linear shoreface slope intersect (Fig. 2) (Ashton et al., 2001). The slope of the shoreface is assumed to be constant and does not evolve morphologically throughout simulations or vary the beach profile. Sediment is not transported out of cells that are shadowed by protruding sections of coastline since they are protected from incoming waves (Fig. 3).

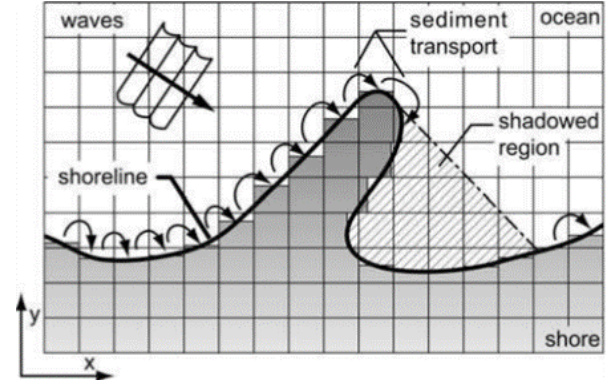

Figure 3. Plan-view schematic of CEM showing the shadow zone that is formed when protruding sections of coastline prevent waves from approaching the shoreline (Ashton and Murray, 2006a).

Where a shoreline cell overfills with sediment $\left(F_{i}>1\right)$, the excess material is deposited in the surrounding empty cells. As new cells become active land cells, the shoreline advances. This redistribution of material has no effect on the topographic profile of the coastline but simply shifts the location of the shoreline to where cells have filled with sediment. If a greater volume of sediment is removed from a cell than it contains, the shoreline retreats. With this one-line approach, the water level in the model is effectively held constant and cannot be varied, which limits its application to studies interested in the influence of sea level change on coastal evolution.

\section{The Coastline Evolution Model 2D (CEM2D)}

CEM2D contains a significant number of modifications to enable it to model the evolution of coastal features, including their topographic profiles, and to study the influence of a variable water level. The model domain is divided into regular square cells of a user-defined size (m), as per CEM (Fig. 4a). The variable $F_{i}$ is not used in CEM2D to represent the partial horizontal fill of sediment, instead each cell contains values for depth of sediment to the continental shelf, elevation of sediment above the water level, or depth of water (Fig. 4b). Having these additional values of sediment fill in the vertical enables CEM2D to represent two-dimensional coastlines with greater topographic detail compared to the original CEM, as illustrated in Fig. 4. Importantly, the twodimensional profile allows the morphology of the beach and shoreface to evolve according to the transport of sediment across the entire model domain. It explicitly models the slope of the continental shelf and shoreface and the morphological profile of the beach and sea floor.

In CEM2D the elevation of each cell relative to the water level is used to classify cells as either wet or dry on each model iteration. The boundary between wet and dry cells is used to locate the shoreline (Fig. 5) using the same shoreline search technique as CEM. The local shoreline orientation is identified by computing the angle between a shoreline cell 

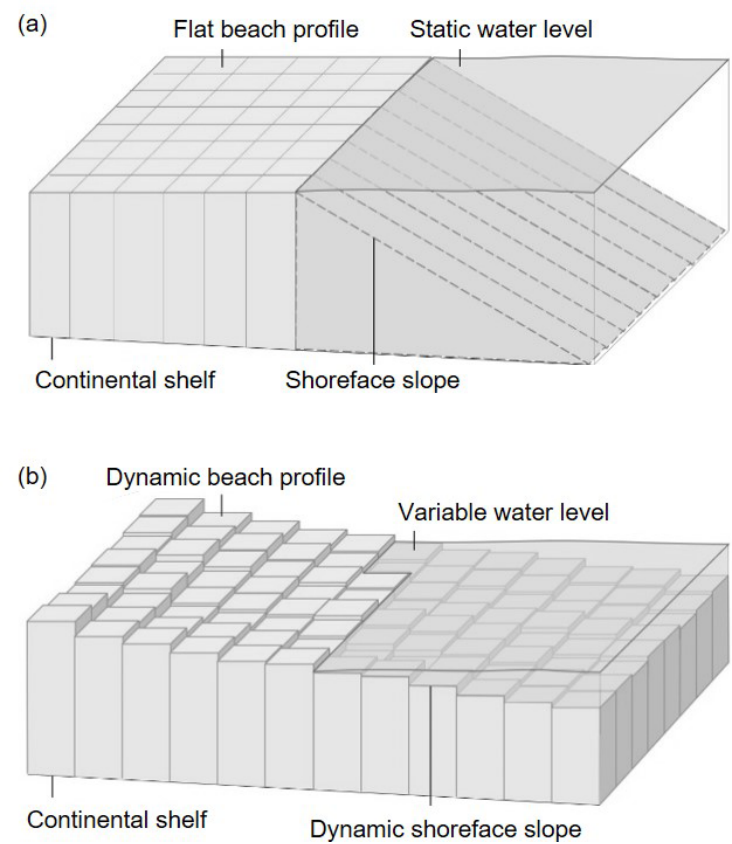

Figure 4. Schematics of the profiles of CEM (a) and CEM2D (b), illustrating the difference in structure and dimensionality of the two models.

and two neighbouring shoreline cells. This forces the shoreline angle to be either $0,22.5,45,67.5$, or $90^{\circ}$. Once the shoreline is located and the local shoreline angle computed as per CEM, linear wave theory is used to transform the offshore wave climate and the CERC formula to calculate sediment flux between the one-line shoreline cells (Eq. 1). The limitations of not calculating the horizontal sediment fill of each cell $\left(F_{i}\right)$ influences the sediment transport equations by reducing the angular resolution of the local shoreline, and it can also lead to a more irregular representation of the shoreline. However, as shown in the results, the model remains capable of simulating fundamental shoreline shapes.

Sediment flux is calculated using the same equations as CEM (Eq. 1), employing threshold-determined upwind or central finite-difference techniques (Ashton et al., 2001; Ashton and Murray, 2006a). However, since CEM2D represents sediment transport in two dimensions, an alternate method for distributing sediment across the surf zone is used. Rather than assuming shore-parallel contours, material is dispersed across the surf zone based on an avalanching scheme that is somewhat similar to that used in other coastal evolution models (e.g. XBeach; Roelvink et al., 2009)(Fig. 6). The method ensures that sediment is distributed across the active profile and remains consistent with transport calculations using the integrated CERC formula but also that there is dynamism in this process that takes into account the elevation of a cell and its neighbours that is consistent with the $2 \mathrm{D}$ representation of the domain.
The sediment distribution method is based on the relationship between the properties of coastal material (e.g. sand, gravel) and slope angle, as shown by McLean and Kirk (1969). We can assume that coastal profiles will in general maintain an average slope angle that is consistent with the grain size of beach material, although there are a range of factors that can cause steepening or shallowing (McLean and Kirk, 1969). To carry out this redistribution procedure, an algorithm sweeps the entire model domain and identifies where a critical angle has been exceeded between a cell and its neighbour (Eq. 3).

$$
\frac{\Delta_{z}}{\Delta_{w}}>m_{\mathrm{cr}}
$$

where $z$ is depth, $w$ is cell width, and $m_{\mathrm{cr}}$ is the critical slope. The material is then redistributed amongst the orthogonal surrounding cells until the critical slope angle is no longer exceeded (Fig. 6).

The sediment metrics are then updated accordingly, including the total volume of material and the cell's elevation above a reference point. The rules defining the sediment redistribution are important parameters that can significantly alter the model outcomes and have therefore been thoroughly tested. The two most critical components are (1) the threshold angle between cells that instigates transport and (2) the frequency that the domain is analysed for these thresholds. These values should be calibrated to allow sediment to be distributed without inducing sediment pilling or deep depressions forming in the domain. Similar techniques are widely implemented in landscape evolution models, such as SIBERIA (Willgoose et al., 1991) and GOLEM (Tucker and Slingerland, 1994; Coulthard, 2001). The implementation of this method in CEM2D allows the nearshore profile to evolve dynamically, rather than assuming an even distribution across the nearshore profile and forming shore-parallel contours, as is the case in CEM and other one-line models. In CEM2D, the ability of the simulated coast to evolve dynamically in this way provides a more realistic representation of the morphodynamic behaviour of these systems. How sediment is distributed can affect the longer-term evolution of the system and record a morphological memory of landforms that can interact with other features as they form and mature (Thomas et al., 2016).

CEM2D's two-dimensional structure allows the water level to be varied, but by default the water level is at $0 \mathrm{~m}$ elevation. There are two dynamic water level modes within the model that can be run independently or in combination that can be used to represent tidal fluctuations and long-term sea level change. The increased complexity of the model domain and of sediment transport processes in CEM2D enable it to model complex two-dimensional coastal profiles and evolve their morphology. The features allow more complex morphodynamic processes to be explored and to investigate not only the evolution of the one-line shore but also the surrounding beach and shoreface. The sediment storage 


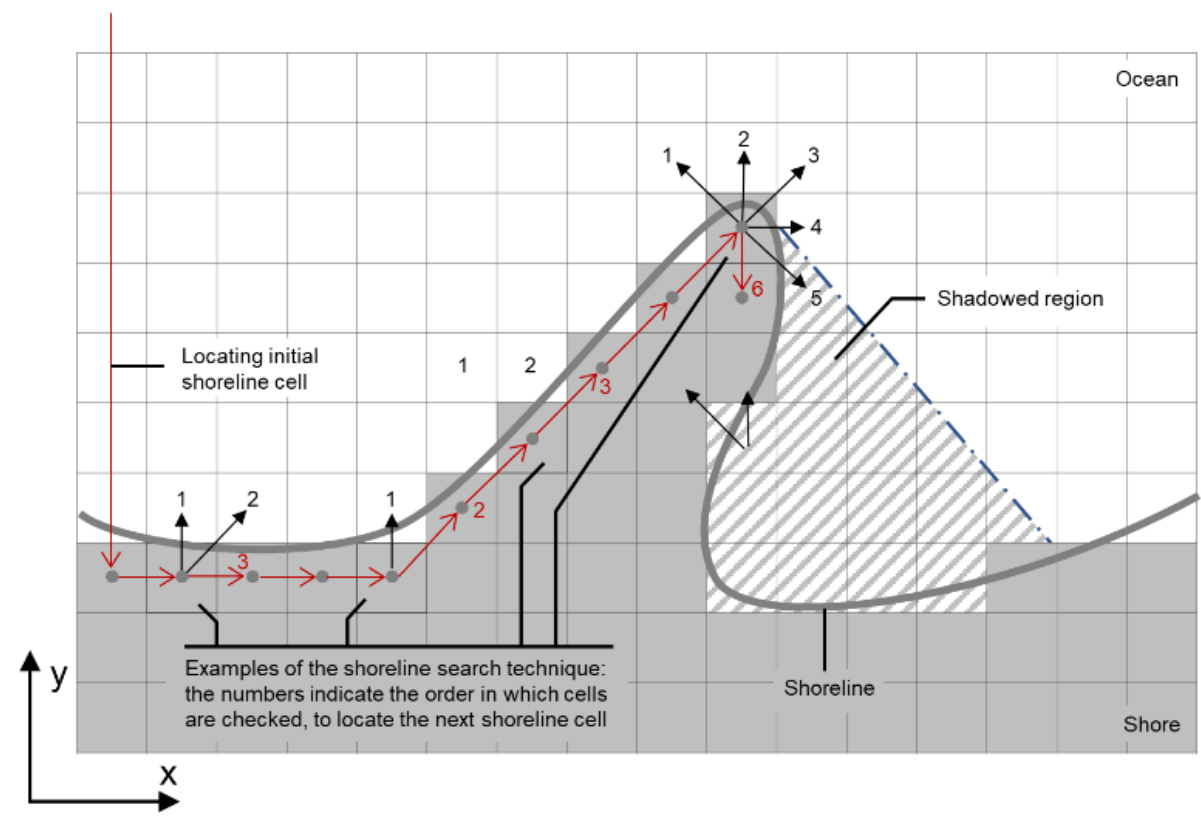

Figure 5. A schematic of the shoreline search technique used in CEM (and CEM2D) to map the $x$ and $y$ locations of the shoreline cells. The number in square brackets denotes the shoreline cell number that is associated with a particular $x$ and $y$ value, and the number on each arrow is the iteration of the clockwise search from the shoreline cell where it originates.

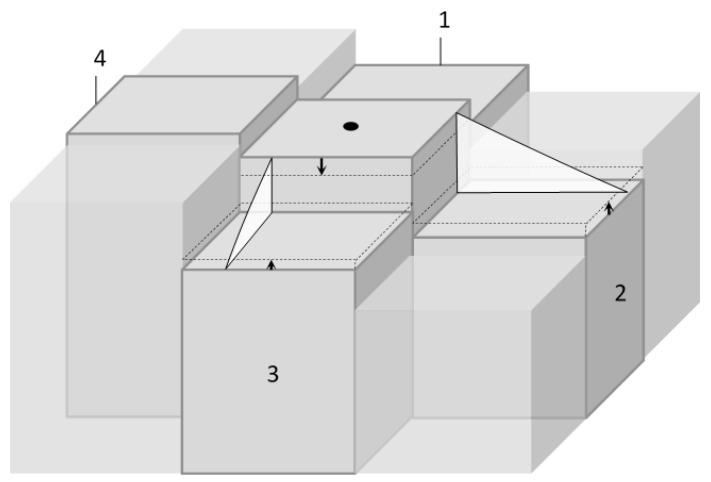

Figure 6. Schematic of the sediment distribution technique used to distribute sediment to cells with lower elevations. In the example, the angle between the central cell and cells [2] and [3] exceeds the threshold for diffusion. Sediment is removed from the central cell and redistributed to these cells. Cells [1] and [4] are not readjusted in this iteration but may be in subsequent sweeps of the coastline.

and handling technique allow complex landforms and features to develop and leave a morphological memory in the bathymetry as they evolve. Sea level change is an important addition to this model that could be used to explore the response of coastal systems to fluctuating water levels and the influence of fundamental climate change effects such as sea level rise.

\section{Methodology: sensitivity analysis and model evaluation}

To evaluate how CEM2D simulates coastal change, CEM2D was compared to CEM outputs as well as to the behaviour and morphology of natural coastal environments. This provides both a check that the new model is able to represent natural systems as in the original and an indication of where the added features (namely 2D operation) might change the model outputs. As the aim of this paper is to describe and highlight the technical developments of CEM2D, we evaluate our simulation results against the original CEM outputs (as subsequently described). Full validation would require time series of bathymetric field data for the duration and range of wave climates and wave directions simulated, and this is not presently available. However, similar to how Ashton and Murray (2006) visually compare their simulation findings to coastal features, including the Carolina Capes, we too compare our outputs to a series of examples.

\subsection{Initial conditions}

CEM and CEM2D were initially set up with a uniform gridded domain measuring 200 (cross-shore) by 600 (alongshore) cells, with a cell size of $100 \mathrm{~m}$ by $100 \mathrm{~m}$ (Fig. 7). A straight planform coastline was used, with uniform undulations along its length. The coastal profile is characterised by a fixed continental shelf slope of 0.1 with a minimum imposed depth of $10 \mathrm{~m}$ and an average shoreface slope of 0.01 . Within CEM2D, these average slopes are imposed across the 


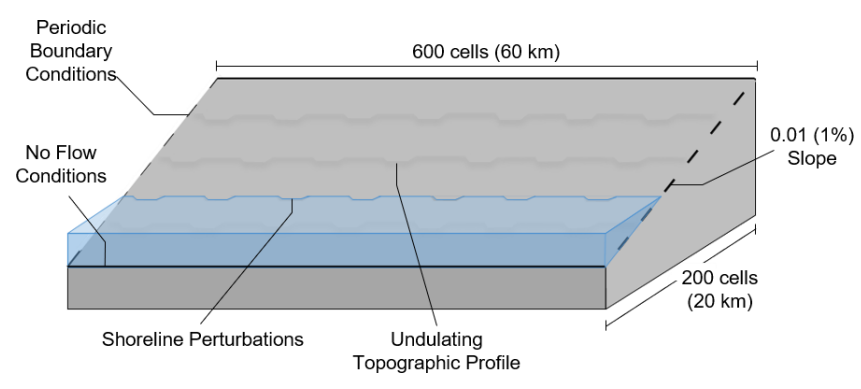

Figure 7. A schematic of CEM2D's model set-up and the initial conditions used for simulations presented in this paper.

two-dimensional domain including the beach and bathymetric profiles that are built to replicate an average coastal profile slope of 0.01 . The left and right boundaries of both model domains are governed by periodic boundary conditions to allow a constant flux of sediment from one end to the other and conserve the volume of material in the system. No-flow conditions were set at the seaward end of the domain to again conserve sediment and prevent any gain or loss of material. A daily model time step is used for all simulations. The models were run over a simulated period of 3000 years to allow time for the model to spin up ( $\sim 10$ years), reduce the potential influence of initial conditions, and allow sufficient time for the coastal systems to evolve.

\subsection{Wave climate conditions}

An ensemble of wave climates was used to drive the model in order to explore the influence of wave conditions on the morphology and evolution of coastal systems. We use the four-binned probability density function (PDF) approach of Ashton and Murray (2006a) to define the proportional asymmetry $(A)$ of waves and the proportion of high-angle waves $(U)$ approaching the coastline, according to the wave crest relative to the average shoreline orientation (Fig. 8). A total of 25 simulations were completed, with $A$ values varying between 0.5 and 0.9 in increments of 0.1 and $U$ values that varied from 0.55 to 0.75 in 0.05 increments. The pseudorandom wave angle was generated for each iteration according to these proportional values. The wave height and period are held constant at $1.7 \mathrm{~m}$ and $8 \mathrm{~s}$, respectively.

\subsection{Water level}

The primary purpose of this paper is to highlight the technical development of CEM2D and demonstrate its additional functionalities. The simulations shown focus on how the coastal systems evolve with an unchanging water level at $0 \mathrm{~m}$ elevation, but results are also given for how an increasing water level at a rate of $2 \mathrm{~m} / 100 \mathrm{yr}$ influences the evolution of four shoreline types: cuspate, sand wave, reconnecting spit, and flying spit. This rate of rise is in line with the UK Climate Projections 2009 (UKCP09) (Jenkins et al., 2009) H++ sce-

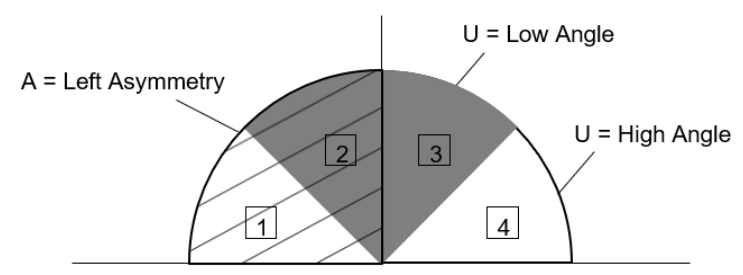

Figure 8. Schematic showing the wave angle direction, defined by the wave climate asymmetry $(A)$ and the proportion of high-angle to low-angle waves $(U)$ with the numbers denoting the four bins.

nario of $0.93-1.9 \mathrm{~m}$ sea level rise by 2100 (Jenkins et al., 2009; Lowe et al., 2009).

\subsection{CEM2D sensitivity analysis}

A sensitivity analysis (SA) technique designed by Morris (1991) and subsequently adapted by Campolongo et al. (2007) was used to identify the relationship between model inputs and outputs by performing multiple local SAs to approximate model sensitivity across a global parameter space. The Morris method's experiment design uses a defined set of values for each input factor, which are discretised into equal intervals and constrained by upper and lower boundaries (Morris, 1991; Ziliani et al., 2013). Each value is altered incrementally per model sensitivity simulation, and the elementary effect of each factor on model outputs is calculated according to the variance of performance indices by Eq. (4):

$d_{i j}=\left(\begin{array}{c}y\left(x_{1} x_{2} \ldots, x_{i-1}, x_{i}+\Delta_{i}, x_{i+1}, \ldots, x_{k}\right) \\ -y\left(x_{1} x_{2} \ldots, x_{i-1,}, x_{i}, x_{i+1}, \ldots, x_{k}\right) \\ \Delta_{i}\end{array}\right)$,

where $d_{i j}$ denotes the value of the $j$ th elementary effect $(j=1, \ldots, r)$ of the $i$ th input factor (and where $r$ is the number of repetitions), $y\left(x_{1} x_{2}, \ldots, x_{k}\right)$ is the value of the performance measure, $k$ is the number of factors investigated, and $\Delta$ is the incremental step value. The main effect is then calculated according to the mean $(\mu)$ of multiple elementary effects computed randomly from the parameter space, which indicates the relative influence of each input factor on model outputs (Ziliani et al., 2013). The standard deviation (SD) is also used to determine which input factors (if any) have nonlinear effects and which have an influence on model output but in combination with other unspecified inputs (Ziliani et al., 2013).

The number of input factors tests and the number of repeats using the Morris method was constrained by resource availability and computational expense. Further, as demonstrated by Skinner et al. (2018), behavioural indices can be used in the place of performance indices where there is a lack of data to populate the performance indices to drive a more qualitative assessment of model sensitivity. A total of eight key input factors were tested against four behavioural 
Table 1. A table listing the eight input factors from CEM2D used in the sensitivity analysis of the Morris method.

\begin{tabular}{|c|c|c|c|c|c|}
\hline Code & Factor & Intervals & Minimum & Maximum & Justification \\
\hline 1 & Wave angle $\left(^{\circ}\right)$ & 5 & 1 & 5 & \multirow{3}{*}{$\begin{array}{l}\text { The wave climate is fundamental to driving sedi- } \\
\text { ment transport processes in CEM2D. }\end{array}$} \\
\hline 2 & Wave height (m) & 5 & 1 & 6 & \\
\hline 3 & Wave period (s) & 5 & 1 & 14 & \\
\hline 4 & $\begin{array}{l}\text { Sediment redistribution } \\
\text { frequency (iterations) }\end{array}$ & 5 & 10 & 50 & \multirow{2}{*}{$\begin{array}{l}\text { The sediment redistribution method is a new } \\
\text { scheme in CEM2D, governed principally by factors } \\
\text { that defined the frequency and threshold for sedi- } \\
\text { ment redistribution. }\end{array}$} \\
\hline 5 & $\begin{array}{l}\text { Sediment redistribution } \\
\text { threshold }(\%)\end{array}$ & 5 & $1(\%)$ & $100(\%)$ & \\
\hline 6 & Water level change (m) & 5 & 0 & 2 & $\begin{array}{l}\text { The ability to induce sea level rise in the model is } \\
\text { a new scheme that requires testing for its influence } \\
\text { on model outputs. }\end{array}$ \\
\hline 7 & Initial shoreline shape & 3 & 1 & 3 & \multirow{2}{*}{$\begin{array}{l}\text { The original CEM claimed to be relatively insen- } \\
\text { sitive to these initial conditions. Increasing the di- } \\
\text { mensionality and complexity of sediment trans- } \\
\text { port in the model warrants that their influence on } \\
\text { CEM2D outputs be evaluated. }\end{array}$} \\
\hline 8 & Domain width (km) & 3 & 1 & 3 & \\
\hline
\end{tabular}

Table 2. A table showing the four behavioural indices used in the Morris method and the frequency that data are recorded in each simulation.

\begin{tabular}{lll}
\hline Number & Behavioural index & Recording frequency \\
\hline 1 & Alongshore sediment transport rate $\left(\mathrm{m}^{3} / 10 \mathrm{yr}\right)$ & $\begin{array}{l}3650 \text { model iterations } \\
(10 \text { simulated years })\end{array}$ \\
& Coastal sinuosity & $\begin{array}{l}3650 \text { model iterations } \\
(10 \text { simulated years })\end{array}$ \\
\hline 3 & The ratio of wet to dry areas & $\begin{array}{l}300 \text { model iterations } \\
(300 \text { simulated days to align with each } \\
\text { diffusion frequency tested })\end{array}$ \\
& & $\begin{array}{l}1095000 \text { model iterations } \\
(3000 \text { simulated years })\end{array}$ \\
\hline 4
\end{tabular}

indices that represented fundamental processes in the model. The input factors were each ranked according to their relative influence on model outputs and to determine which input factors, if any, have non-linear effects and which have an influence on model output but in combination with other unspecified inputs (Ziliani et al., 2013). The factors tested are given in Table 1, and the behavioural indices are given in Table 2 .

\section{Results}

\subsection{CEM2D sensitivity analysis}

The mean and standard deviation of each input factor on each behavioural index is given in Fig. 9. The higher the mean, the greater the influence of that factor on model outputs, and the higher the standard deviation, the greater the non-linearity; non-linearity refers to the non-sequential effects of the given factor on model sensitivity or that it influences model behaviour through complex input-input interactions (Ziliani et al., 2013; Skinner et al., 2018). The results show the principal input factors that (1) have the greatest influence on model sensitivity (e.g. wave angle, wave height, sediment distribution factors), (2) those that have a negligible influence (e.g. wave period and domain characteristics), and (3) those that show non-linear behaviours or interactions that can amplify variance in model outputs (those that also have the greatest influence on model behaviour, e.g. the wave angle). The results further highlight input factors that can have an influence on model outputs but only according to specific behavioural indices (e.g. water level and domain characteristics). It is important to note that the results of the SA can be influenced by the input factors used, the range of values, and the behavioural indices that are chosen to assess sensitivity. 

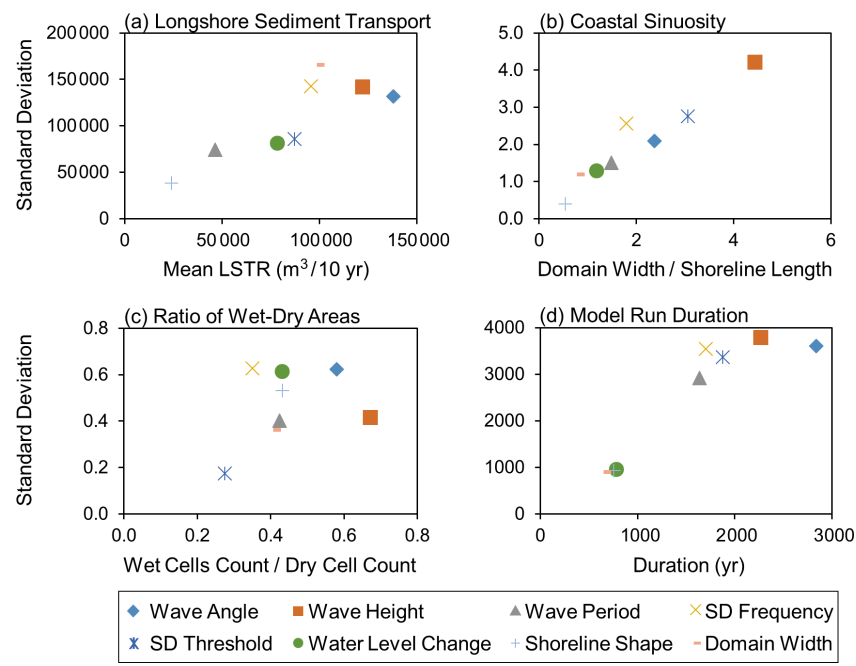

Figure 9. The mean and standard deviation of results from the input factors, according to the four behavioural indices labelled (a)-(d).

Aggregating the results from the four behavioural indices shows that the wave angle and height have the highestranking influence on model behaviours, followed by sediment distribution factors, and the domain set-up is considered the least influential (Fig. 9). Factors that rank highly based on the mean also tend to show greater non-linearity and have complex interactions with other inputs. It is also found, however, that the rankings of the various input factors differ according to the behavioural indices used to assess model sensitivity, each of which describes a different behaviour in the model. For instance, the water level shows a high influence on model behaviour when assessed against the ratio of wet to dry cells but according to the sinuosity of the shoreline is ranked just below average. The selection of model parameters, described in Sect. 4, was driven by the results of the $\mathrm{SA}$, and particular attention was given to constraining optimum wave climate conditions and sediment distribution parameters through a series of further behavioural sensitivity testing.

\subsection{Fundamental shoreline features}

The ensemble plots in Figs. 10 and 11 show final coastal morphologies produced from CEM and CEM2D, respectively, according to the 25 wave climate conditions. Both models demonstrate how different planform shoreline shapes evolve according to the wave climate scenarios, as previously demonstrated by Ashton and Murray (2006a). The proportion of high-angle waves influences cross-shore sediment transport and the extent to which landforms accrete seaward, whilst the wave asymmetry determines the balance of crossshore to alongshore transport and the planform skew of features. It is found that there is some directional bias in the source code that drives a alongshore current independent of the wave climate conditions. This directional bias is more ap- parent in CEM2D and particularly where the wave climate is symmetrical $(A=0.5)$. It also drives some migration of the cuspate landforms downdrift, but a similar rate of movement is recorded in both CEM and CEM2D at 1.6 and $1.7 \mathrm{~m}$ per year, respectively. The directional bias is induced by calculations in the model that process from the left to the right of the domain. In future model versions, the routines will require updating, which would also necessitate that sediment transport methods be altered accordingly.

Four principal shoreline shapes evolve under the driving wave conditions, including cuspate forelands, alongshore sand waves, reconnecting spits, and flying spits. CEM2D shows a greater sensitivity to input variables compared to the CEM, which is apparent in the development of these four feature types. In CEM2D a greater distinction is made between reconnecting and flying spits due to the increased complexity of CEM2D's sediment handling and distribution methods. The distribution method allows sediment accumulations to be detached from the continuous shoreline without becoming static, and thus transport across the entire domain, including on the lee side of a spit, is less limited. Each of these four features types are compared to natural systems subsequently that are subject to comparable wave climate conditions.

\subsubsection{Cuspate forelands}

Symmetrical wave climate conditions $(A=0.5)$ are shown to form cuspate forelands in CEM and CEM2D, which compare to those found along many shorelines globally. The Carolina Capes span parts of North Carolina and South Carolina coast in the USA and are used as a case site by Ashton and Murray (2006b) against results generated by CEM. The wave climate along this stretch of coastline is characterised by highangle waves of relative symmetry, which broadly equate to PDF values of $A=0.55$ and $U=0.6$ (Ashton and Murray, 2006b). Placing the Carolina Capes into the context of the results shown in Fig. 11, CEM2D would model a cuspate coastline that is slightly skewed due to the $5 \%$ dominance of left-approaching waves. The wave direction plays a significant role in the formation of the features, with the slightly stronger southerly current skewing the tips of the landforms (Park and Wells, 2005). Considering that all site-specific conditions controlling the evolution of capes are not represented in CEM2D or CEM, the models are able to predict a comparable shoreline type to that observed in this natural system. However, CEM2D overpredicts the directional skew, and thus CEM may be the preferred option in this instance.

\subsubsection{Alongshore sand waves}

A slight asymmetry in the wave climate (where $A=0.6$ ) generates alongshore sand waves in both CEM (Fig. 10) and CEM2D (Fig. 11). However, CEM2D has a greater sensitivity to this parameter and the features show a greater skew downdrift. For instance, under $A=0.6$ and $U=0.75$ cuspate 


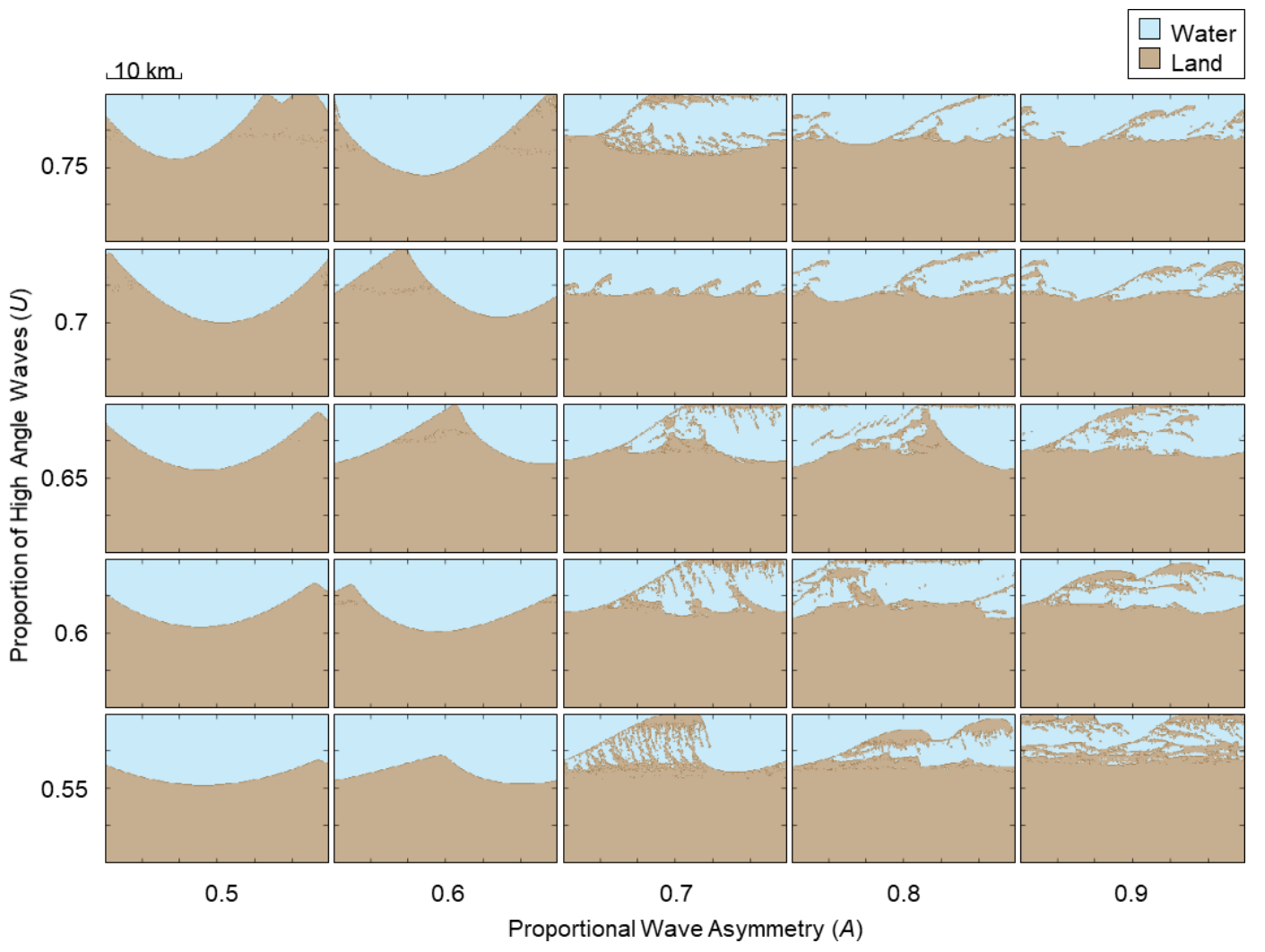

Figure 10. A matrix of results from CEM showing final shoreline morphologies as a function of the wave angle asymmetry $(A)$ and proportion of high-angle waves $(U)$ approaching the coast relative to the local shoreline orientation. The outputs measure $20 \mathrm{~km}$ in width and $30 \mathrm{~km}$ in length and are not inclusive of the periodic boundaries.

sand waves form along the shoreline in CEM, but in CEM2D the features skew and hooks form at the distal points. Comparing these results to the planform morphology of sand waves found in natural systems, such as Benacre Ness in the UK, which has PDF values of $A=0.6$ and $U=0.8$, demonstrates the ability of CEM2D to reflect the asymmetry of landforms formed under asymmetric wave climate conditions compared to CEM; CEM2D may, therefore, be the preferred model in this instance. However, it is noted that site-specific environmental and boundary conditions play a role in the formation and evolution of Benacre Ness that are not modelled by either software and that the wave transformation equations used may not be wholly suited to this site.

\subsubsection{Reconnecting and flying spits}

Under high asymmetric wave climate conditions dominated by high-angle waves, spits form along the shoreline in CEM (Ashton and Murray, 2001; Ashton et al., 2006b) and CEM2D. However, CEM2D again shows a greater sensitivity to the wave climate conditions, with more distinction made between reconnecting and flying spits due to the refinement of sediment handling techniques in the model.
Ashton and Murray (2006b) compare results from CEM to the behaviour and development of the reconnecting Long Point Spit in Lake Erie, Canada, where the wave climate is characterised by high asymmetry $(A=0.8-0.9)$ and highangle wave dominance $(U=0.6-0.7)$ (Ashton and Murray, 2006b). Under all four potential wave climate conditions, reconnecting spit features form in CEM (Fig. 10), whereas in CEM2D (Fig. 11) either sand waves or reconnecting spits form depending on the combination of $A$ and $U$ values within the given ranges. Ashton and Murray (2007) suggest that the wave climate is favoured towards an asymmetry $(A)$ of 0.8 along the entire spit, and under these conditions reconnecting spits form in CEM2D (Fig. 11), suggesting that CEM2D may be there preferred tool to use in this conditions. The presentation of both sand waves and reconnecting spits in CEM2D would suggest that this model may be able to better represent the conditions found at Long Point Spit.

Comparing model results to flying spits, Spurn Point in the UK extends off the southern end of the Holderness coast and has a PDF wave climate of $A=0.75, U=0.35$. Following the pattern of results from CEM (Fig. 10) and CEM2D (Fig. 11), where there is proportional asymmetry $(A)$ of between 0.7 and 0.8 , net alongshore sediment transport forms these types of landforms. However, in CEM2D these fea- 


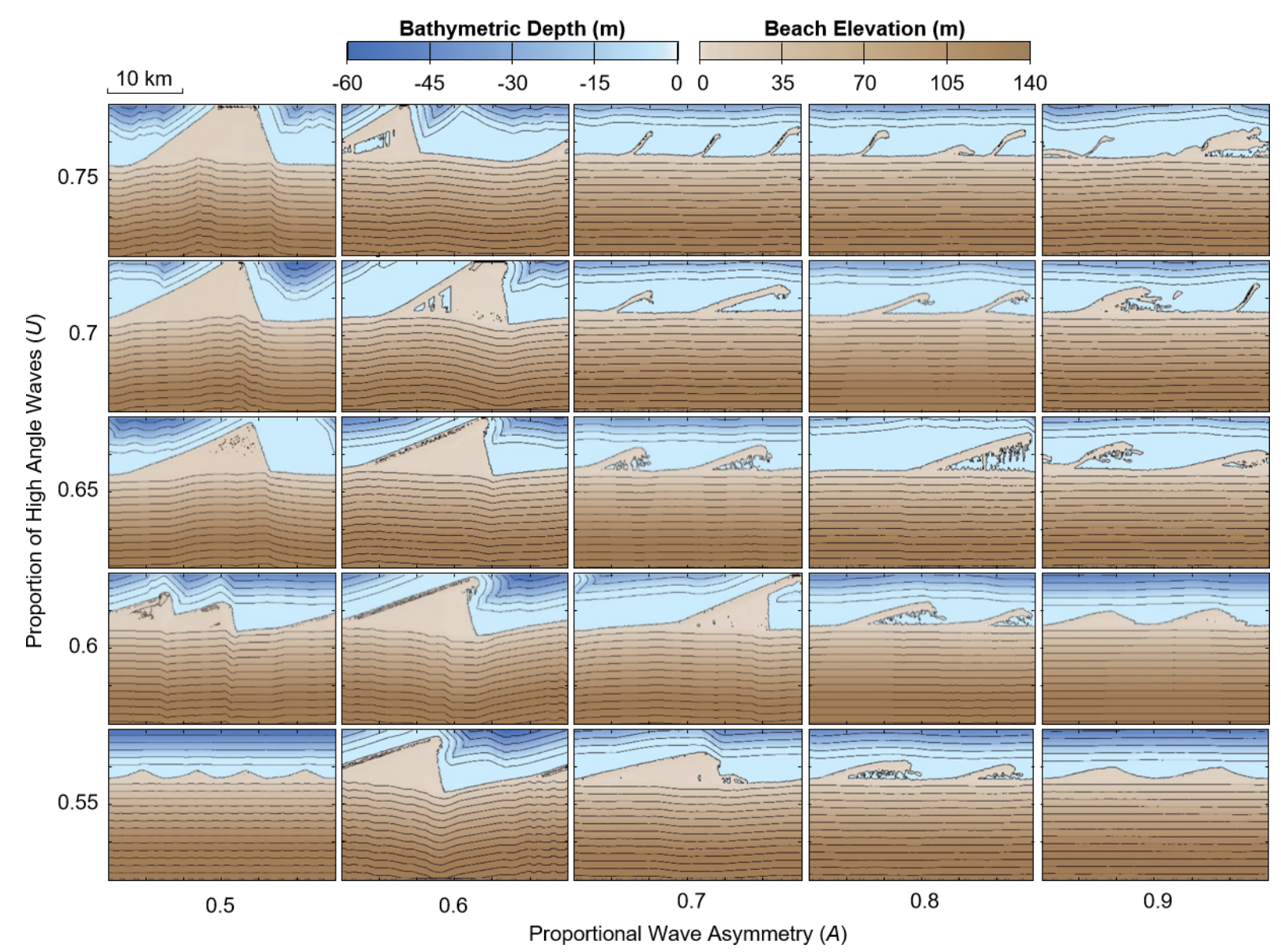

Figure 11. A matrix of results from CEM2D, showing two-dimensional final shoreline morphologies as a function of the wave angle asymmetry $(A)$ and proportion of high-angle waves $(U)$ approaching the coast relative to the local shoreline orientation. The outputs measure $20 \mathrm{~km}$ in width and $30 \mathrm{~km}$ in length and are not inclusive of the periodic boundaries.

tures fluctuate between spits and sand waves owing to the strong alongshore current generated by the low-angle waves and high asymmetry. Whilst CEM2D better represents the influence of low-angle waves on coastal evolution at Spurn Point, it is of note that this is a complex feature that is influenced by conditions that could be having a greater impact on coastal evolution, including estuarine processes and dredging activities, that are not included in either CEM or CEM2D.

\subsection{Spatial scale of shoreline features}

The spatial scale of shoreline features differs between results from CEM and CEM2D. Metrics from the end of each run, as shown in Figs. 10 and 11, show that larger features evolve in CEM2D in six of the simulations. The larger features evolve under wave climate conditions where $A=0.6$ and $U=0.55-0.65$ (sand waves), where $A=0.7-0.8$ and $U=0.7$ (flying spit), and where $A=0.9$ and $U=0.75$ (flying spit), and smaller features evolve in the remaining 19 simulations. However, each run terminates at a different time step, and a comparison of results at the earliest termination

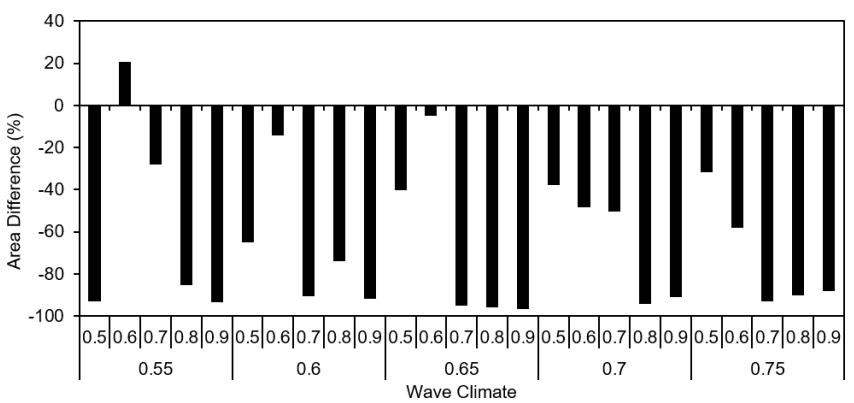

Figure 12. Areal difference (\%) between results of CEM2D to CEM. The wave climate given along the $x$ axis is defined according to the wave asymmetry (top row) and the proportion of high-angle waves (bottom row).

for each pair of simulations shows that in all but one of the runs ( $A=0.6, U=0.55)$ the features are smaller and less developed in CEM2D than the CEM (Fig. 12).

Whilst CEM and CEM2D are not designed to represent the temporal evolution of specific coastal environments, and 


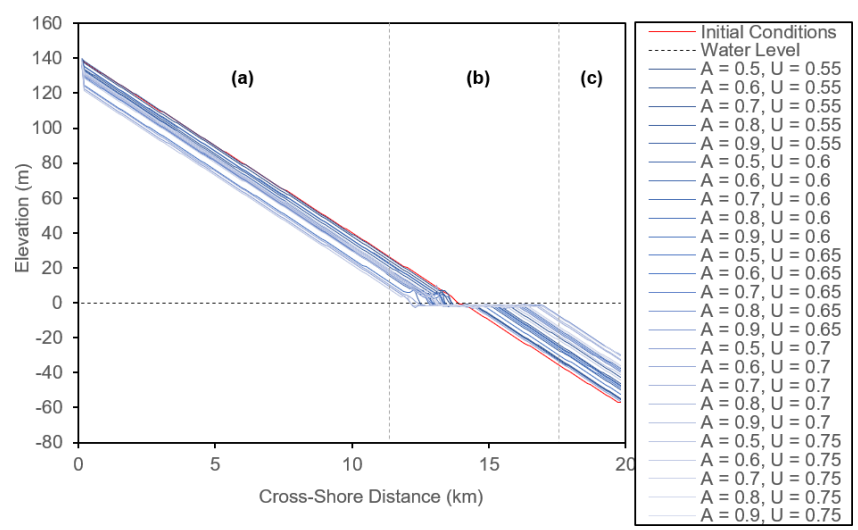

Figure 13. Cross-shore profiles taken for each of the 25 simulations, with water level shown as a dashed line and the initial cross-shore profile shown as a solid red line. Labelled are the (a) beach surface, (b) dynamic shoreline and upper nearshore, and (c) the lower nearshore.

thus this metric should not be compared between the models (Ashton and Murray, 2006a), we note that the evolution of landforms is more gradual in CEM2D. This is likely as a result of differences in the representation of the domain and in the distribution of sediment. Rather than sediment being distributed evenly across the nearshore to the depth of closure as in CEM, CEM2D uses the sediment distribution method to route sediment along lines of steepest descent and spreads available material across the nearshore profile. This leads to the formation of both shoreline features and a shallow nearshore shelf (see Sect. 5.4).

Highlighted above are differences in results between CEM and CEM2D and in particular the complexity of results generated in CEM2D due to the addition of a dynamically evolving profile. In nature, the features discussed evolve at different rates and to different spatial scales, and in order to use CEM2D to investigate such systems, parameters in the model including the threshold and frequency of sediment distribution should be adjusted to suit the specific environment studied and the rates at which these features form.

\subsection{Dynamic coastal profile}

The novel development of CEM2D is to simulate variations in the nearshore topography. Of particular interest are the dynamics of the upper nearshore, which evolves under the influence of sediment exchange with the shoreline (Fig. 13b). The lower nearshore profile tends to be influenced to a lesser degree (Fig. 13c) and consequently is able to store remnants of morphological features as they evolve.

One-line models tend to assume that contours lie parallel to the shoreline, but the results in this study demonstrate that the bathymetric profile in particular is highly dynamic (Fig. 13). Whilst some of the results of CEM2D show a profile with shore-parallel contours, the majority do not exhibit this behaviour, particularly where there is a strong asymmetry in the wave climate (Fig. 13). The shoreline and bathymetry is not solely influenced by current environmental conditions but is also influenced by previous states and morphological residuals. Omitting or smoothing the bathymetry in the representation of coastal systems could have implications for their long-term evolution. The effect of morphological inheritances have been previously suggested by authors including Wright and Short (1984), French et al. (2015), and Thomas et al. (2016). Many of the results from CEM2D have noted the presence of remnant features or states in the coastal profile, particularly in the nearshore zone. The presence of these features is strongly attributed to the balance of cross-shore and alongshore sediment transport and the rate of change. For instance, where sand waves form, the rate of change is such that the alongshore movement of landforms makes an impression in the profile that is significant enough to be sustained in the bathymetry as the features migrate (Fig. 14). However, where reconnecting spits form along the shoreline, the rapid rate of alongshore and cross-shore sediment transport acts to smooth the profile and remove evidence of predeceasing morphologies (Fig. 14). These processes could prove important for understanding the nearshore dynamics of natural coastal environments, particularly under changing environmental conditions.

Relative rates of morphological change and coastal dynamics differ according to the driving wave conditions (Fig. 15). This is illustrated in the volume stacks in Fig. 15, which present the change in volume of sediment across a transect $(x=30 \mathrm{~km})$ every 30 simulated years for four wave climate scenarios: $A=0.5$ and $U=0.55$ (Fig. 15a), $A=0.6$ and $U=0.6$ (Fig. 15b), $A=0.7$ and $U=0.65$ (Fig. 15c), and $A=0.8$ and $U=0.7$ (Fig. 15d). With increasing wave asymmetry and proportions of high-angle waves, the active cross-shore zone exhibits greater dynamism and greater volumes of net alongshore transport. However, the results also show that these systems have complex non-linear behaviours that emerge from the balance of alongshore and cross-shore sediment transport.

\subsection{Variable water level}

Changing the water level against the dynamic topography allows CEM2D to explore how a rising water level might affect how coastal systems behave. The results demonstrate that a rising sea level causes landward recession of the shoreline and uplift of the profile (Fig. 16), as is commonly held (Dickson et al., 2007; Bird, 2011). The rate of recession is broadly within 2 orders of magnitude the rate of sea level rise, prescribed at $2 \mathrm{~m} / 100 \mathrm{yr}$ in the simulations, which is in agreement with Bruun rule estimations (Bruun, 1962). Variations in the rate of recession and morphology of the cross-shore profile are, however, observed with different wave climate conditions that differ in the balance of cross-shore and alongshore flows (Fig. 16). 

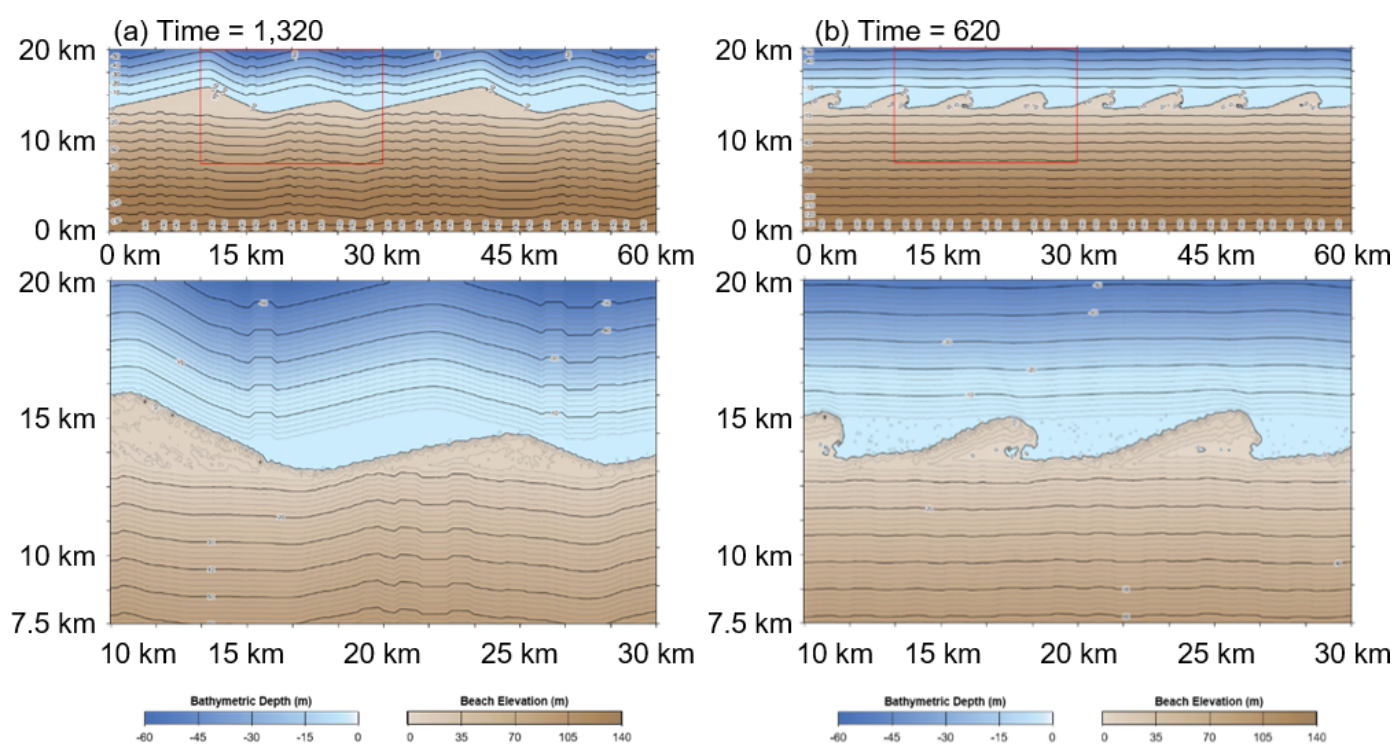

Figure 14. Morphology plots showing outputs of (a) $A=0.6$ and $U=0.6$ at time $=1320$ years and (b) $A=0.7$ and $U=0.65$ at time $=620$ years.

As in Fig. 15, Fig. 17 shows the change in volume of sediment across a transect $(x=30 \mathrm{~km})$ every 30 simulated years for four wave climate scenarios: $A=0.5$ and $U=0.55$ (Fig. 17a-b), $A=0.6$ and $U=0.6$ (Fig. 17c-d), $A=0.7$ and $U=0.65$ (Fig. 17e-f), and $A=0.8$ and $U=0.7$ (Fig. 17gh). The figure shows a comparison of the results with a static water level (top) and with a rate of sea level rise of $2 \mathrm{~m} / 100 \mathrm{yr}$ (bottom). The spatial extent of morphological change is more diverse and widespread when the systems are subject to sea level rise. The principal active zone also tracks backwards as the water level rises and the shoreline recedes.

A rising sea level influences the evolution of shoreline features that evolve in the model, including cusps (Fig. 18a), sand waves (Fig. 18b), reconnecting spits (Fig. 18c), and flying spits (Fig. 18d). As also shown in Fig. 18, recession of the shoreline is observed in all four coastal systems as the water level rises regardless of the wave climate conditions (also shown in Fig. 16). Where the wave climate is symmetrical, cuspate features form under a static water level but have a slight asymmetry under sea level rise conditions, where the direction bias in the model is exaggerated. The cusps extend further offshore where the bays between the headlands are eroded, increasing wave shadowing and hence exaggerating the effects of the directional bias. A slight asymmetry in the wave climate forms sand waves along the shoreline (Fig. 18b), but submergence of these features under a rising sea level leads to the formation of a waterbody in the low-lying interior of the landform. Where the wave climate is defined by $A=0.7$ and $U=0.65$ (Fig. 18c), reconnecting spits form when the water level is static, but as the water level rises the pathways that reconnect the spit to the mainland are submerged. In Fig. 18d, flying spits are shown to evolve with and without sea level rise, where the wave climate is highly asymmetric. The difference between these two simulations is that under a rising water level, the flying spits keep pace with the migrating shoreline and also cycle through submergence and reformation, as they are drowned by the rising water, but new features are able to form due to the high rate of alongshore sediment transport. Remnants of the submerged spits remain in the nearshore and promote the development of spits in these areas due to the shallower water and also influence the unique plan-form morphology of the features.

Observing the effects of sea level rise on coastal features, including their ability to migrate with the shoreline or how their morphology changes at this temporal scale is challenging. Evidence of submerged shorelines and landforms that formed during transgressive periods can be removed by highenergy waves and storm events, rapid migration of systems, and sediment transport that consumes or removes remnant features (Shaw et al., 2009). Notable submerged shorelines are found in the Bras d'Or Lakes, Nova Scotia, and are suggested to have been well preserved by the rapid onset of sea level rise (Shaw et al., 2009). Tombolos, spits, cuspate forelands, and barrier beaches are identifiable on multibeam sonar imagery in the lakes down to $-24 \mathrm{~m}$, above the early Holocene water level at $-25 \mathrm{~m}$ (Shaw, 2006). Evidence of enclosed bodies of water within cuspate forelands and the stranding of landforms at this lower sea level demonstrate in situ drowning and the preservation of landforms between -7 and $-24 \mathrm{~m}$ shows the ability of some landforms to migrate (Shaw, 2006; Shaw et al., 2009). Barrier islands and spits in the Bras d'Or Lakes are also found to rebuild at the proximal end of previously submerged landforms (e.g. Dhu Point and West Settlement) or migrate landward to form cuspate 


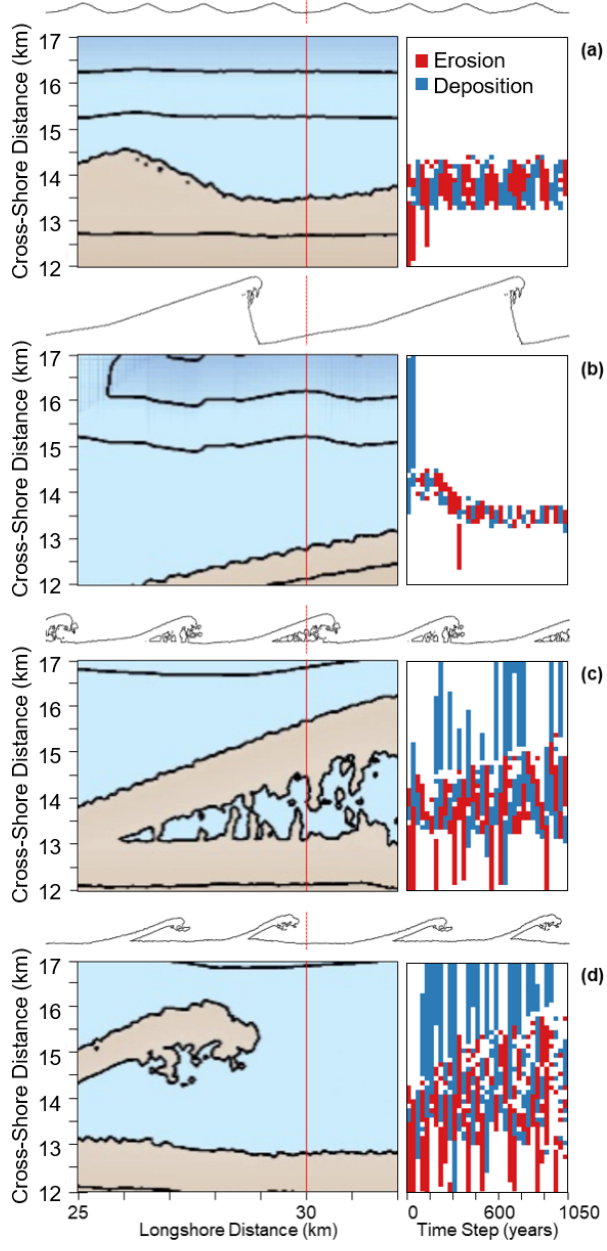

Figure 15. Shoreline morphologies (left) and volume stacks (right) for four simulations where the wave climate is defined by (a) $A=0.5$ and $U=0.55$, (b) $A=0.6$ and $U=0.6$, (c) $A=0.7$ and $U=0.65$, and (d) $A=0.8$ and $U=0.7$. The red line marks the cross-shore transect where the change in volume at 30 -year time intervals is recorded.

barriers in response to rising water levels (e.g. Goose Pond) (Taylor and Shaw, 2002).

\section{Discussion}

The purpose of this study was to provide an overview of the development and application of CEM2D and its ability to represent coastal systems compared to other existing coastal evolution models of its kind. The behaviour of the model has been evaluated against results from the existing Coastline Evolution Model (CEM), upon which CEM2D has been built. Results have also been compared to accepted theories of coastal morphodynamics and to the behaviour of a number of natural coastal environments. These evaluation techniques have demonstrated that CEM2D is able to simulate shoreline instabilities in accordance with theories of high-angle wave

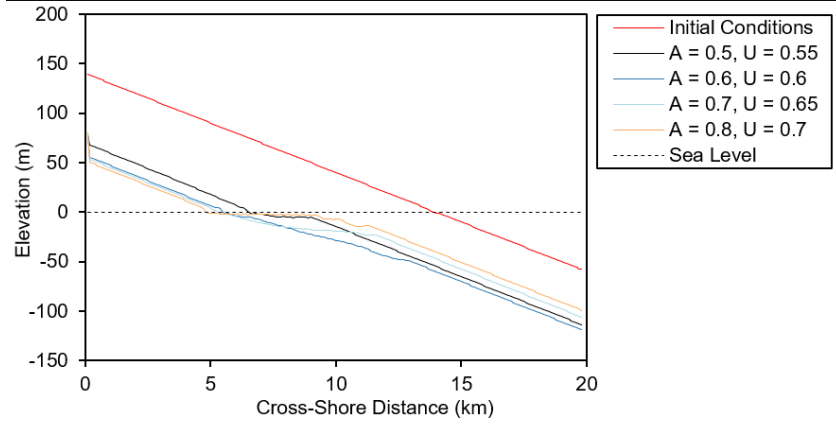

Figure 16. Cross-shore coastal profiles for four simulations where the wave climate is defined by (a) $A=0.5$ and $U=0.55$, (b) $A=0.6$ and $U=0.6$, (c) $A=0.7$ and $U=0.65$, and (d) $A=0.8$ and $U=0.7$. The initial profile is given as a solid red line, and the water level is given as a dashed black line.

instability, mimic the behaviour of natural environments under given wave climate conditions, and generally reproduce the results of the original one-line CEM, although some differences are observed, as discussed throughout (Ashton and Murray, 2006a). In particular, the results show that CEM2D shows increasing model performance with increasing wave asymmetry compared to CEM. This is likely due to its ability to handle detached sediment accumulations that form during the evolution of reconnecting and flying spits under these wave conditions. It may, therefore, be more appropriate to use CEM2D over CEM when modelling environments with asymmetric wave climates, but CEM where the wave approach is highly symmetrical. Overall, our results show the sensitivity of coastal systems to driving environmental conditions and in particular their response to changing wave climates, which supports theories of high-angle wave instability.

Importantly, restructuring and increasing the dimensionality of sediment transport in the model allows us to explore how the profile of the coastal system changes with the shape of the shoreline, as well as concepts such as morphological inheritance. Where this is considered particularly important or of interest, CEM2D would be the preferred model to use over CEM. In many one-line models, the cross-shore profile of the coastline is kept constant, and it is assumed that its core geometric properties are retained over meso-spatiotemporal scales. Whilst this is a well-used concept, there are advantages to modelling the topography and bathymetry of the coastline, and it is necessary if we are to model the effect of a variable water level. For example, we can see that the nearshore evolves at a greater rate compared to the lower shoreface profile, supporting the theories of Stive and de Vriend (1995). The distribution of sediment across the profile is more transient towards the shore where the greatest volume of transport occurs. However, the geometry of the entire shoreface and the geometric demand for sediment distribution means that material is moved to the lower shoreface 

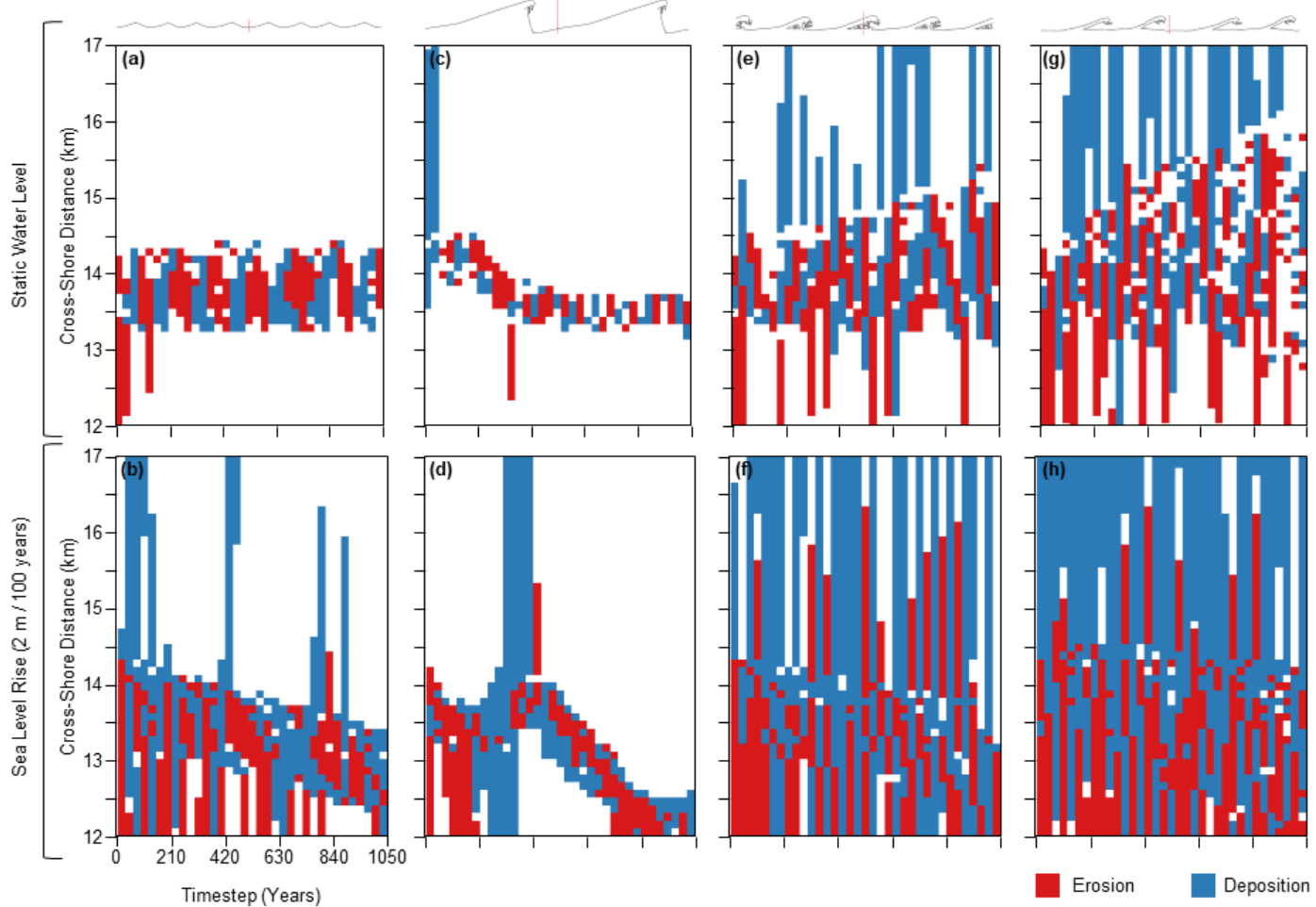

Figure 17. Volume stacks for four wave climate conditions defined by (a, b) $A=0.5$ and $U=0.55,(\mathbf{c}, \mathbf{d}) A=0.6$ and $U=0.6,(\mathbf{e}, \mathbf{f}) A=0.7$ and $U=0.65$, and $(\mathbf{g}, \mathbf{h}) A=0.8$ and $U=0.7$. Results with a static water level are shown along the top row (a, $\mathbf{c}, \mathbf{e}, \mathbf{g})$, and those with sea level rise at a rate of $2 \mathrm{~m} / 100 \mathrm{yr}$ are shown along the bottom row $(\mathbf{b}, \mathbf{d}, \mathbf{f}, \mathbf{h})$. The shoreline outlines at the top of the figure are taken from the static water level scenarios, and the red line marks the cross-shore transect where the change in volume at 30-year time intervals is recorded.

(a) $\mathrm{A}=0.5, \mathrm{U}=0.55$

Static wave level

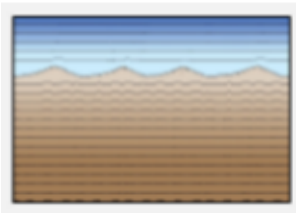

(c) $A=0.7, U=0.65$

Static wave level

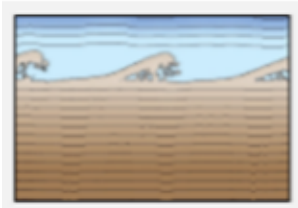

Sea level rise

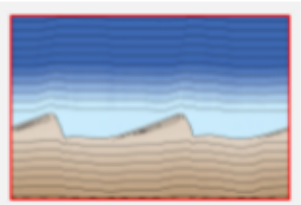

Sea level rise

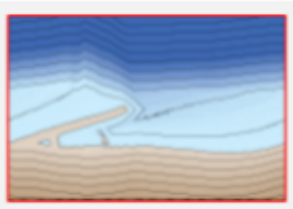

(b) $\mathrm{A}=0.6, \mathrm{U}=0.6$

Static wave level

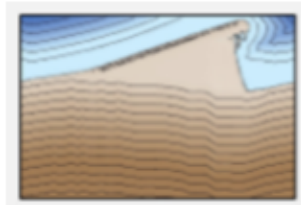

(d) $\mathrm{A}=0.8, \mathrm{U}=0.7$

Static wave level

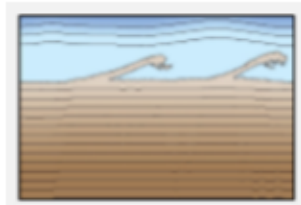

Sea level rise $\quad 40 \mathrm{~km}$

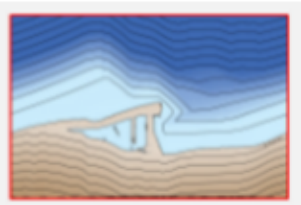

Sea level rise

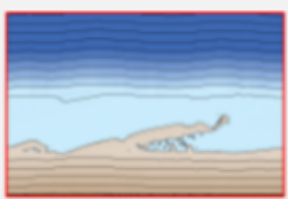

Figure 18. Coastal morphologies for four simulations where the wave climate is defined by (a) $A=0.5$ and $U=0.55$, (b) $A=0.6$ and $U=0.6$, (c) $A=0.7$ and $U=0.65$, and (d) $A=0.8$ and $U=0.7$, run with two water level scenarios including a static water level (left, black outline) and a rising sea level at a rate of $2 \mathrm{~m} / 100 \mathrm{yr}$ (right, red outline).

over time but at a relatively slower rate (Stive and de Vriend, 1995). Further, the topographic profile of coastal landforms is indicative of their formation and evolution, highlighting patterns in sedimentation and drift processes. Using CEM2D to model how this profile changes over time can inform the stability and future behaviour of features.

The alongshore sediment transport equations in CEM2D are inherited from the CEM and currently do not take into consideration the water depth or how far from the shore 
the waves break. Since the water depth can now be calculated within this 2D model, future developments of CEM2D will focus on a revision of the sediment transport equation and include a more suitable calculation that can take advantage of the increased complexity and added functionalities in CEM2D.

A key component of CEM2D is its variable water level, which offers an added advantage over the use of CEM particularly when considering the impacts of sea level rise over the timescales these models are intended for. If we are to explore coastal evolution over the mesoscale, being able to model the effect of rising sea levels is essential. Whilst we have not exhausted the uses of this function here, we have demonstrated its development and how it is facilitated in the model. The power of this tool is vast and will be particularly useful for coastal managers, who must plan for the dynamic evolution of these system over time periods that will be highly influenced by the effects of climate change.

\section{Conclusion}

Here we have presented the development of CEM2D from its one-line origins. We have described the structure of the model, outlined the governing mathematical equations, presented outputs from the sensitivity testing, and evaluated CEM2D's ability to simulate the behaviour and evolution of coastal systems, by comparing it against other model results, theories of coastal evolution, and natural systems. The results demonstrate the validity of the model by its ability to simulate fundamental coastal shapes as per CEM and in comparison to natural coastal systems. Using the added functionalities, we have also shown how CEM2D can be used to explore the two-dimensional behaviour and morphodynamic evolution of coastlines and depositional features over mesospatiotemporal scales. From the results shown here, it is apparent that the model will enable us to conduct interesting and insightful investigations to answer research questions, including how coastal systems behave under changing environmental conditions and how sea level change might influence their morphodynamic behaviour.

Code availability. The current version of the Coastline Evolution Model 2D (CEM2D) is available from the project website (https://sourceforge.net/projects/ coastline-evolution-model-2d/, last access: 16 August 2021) and on Zenodo (https://doi.org/10.5281/zenodo.3341888, Leach, 2019) distributed under the terms of the GNU General Public License.

Data availability. The datasets used in this publication can be accessed through Zenodo (https://doi.org/10.5281/zenodo.5242895, Leach et al., 2021).
Author contributions. All authors contributed to writing and editing this manuscript. The research and software development was led by CL, with extensive support from $\mathrm{TC}$ and $\mathrm{AB}$.

Competing interests. The authors declare that they have no conflict of interest.

Disclaimer. Publisher's note: Copernicus Publications remains neutral with regard to jurisdictional claims in published maps and institutional affiliations.

Acknowledgements. This research was funded by the UK Environment Agency, the NERC-funded British Geological Survey, and the Energy and Environment Institute at the University of Hull.

Financial support. This research has been supported by the UKRI (grant no. NE/R009007/1).

Review statement. This paper was edited by Min-Hui Lo and reviewed by Eli D. Lazarus and two anonymous referees.

\section{References}

Antolínez, J. A. A., Méndez, F. J., Anderson, D., Ruggiero, P., and Kaminsky, G. M.: Predicting Climate-Driven Coastlines With a Simple and Efficient Multiscale Model, J. Geophys. Res.-Earth Surf., 124, 1596-1624, https://doi.org/10.1029/2018JF004790, 2019.

Ashton, A. and Murray, B.: High-angle wave instability and emergent shoreline shapes: 1. Modeling of sand waves, flying spits, and capes, J. Geophys. Res., 111, F04011, https://doi.org/10.1029/2005JF000422, 2006a.

Ashton, A. and Murray, B.: High-angle wave instability and emergent shoreline shapes: 2 . Wave climate analysis and comparisons to nature, J. Geophys. Res.-Earth Surf., 111, F04012, https://doi.org/10.1029/2005JF000423, 2006b.

Ashton, A., Murray, B., and Littlewood, R.: The response of spit shapes to wave-angle climates, in: Coastal Sediments'07, edited by: Kraus, N. and Rosati, N., American Society of Civil Engineers, New Orleans, LA, 2007.

Ashton, A., Murray, B., and Arnault, O.: Formation of coastline features by large-scale instabilities induced by high-angle waves, Nature, 414, 296-300, https://doi.org/10.1038/35104541, 2001.

Bird, B.: Coastal Geomorphology: An Introduction, John Wiley \& Sons, 2011

Campolongo, F., Cariboni, J., and Saltelli, A.: An effective screening design for sensitivity analysis of large models, Environ. Model. Softw., 22, 1509-1518, https://doi.org/10.1016/J.ENVSOFT.2006.10.004, 2007.

Coulthard, T.: Landscape evolution models: a software review, Hydrol. Process., 15, 165-173, https://doi.org/10.1002/hyp.426, 2001. 
Dickson, M. E., Walkden, M. J. A., and Hall, J. W.: Systemic impacts of climate change on an eroding coastal region over the twenty-first century, Clim. Change, 84, 141-166, https://doi.org/10.1007/s10584-006-9200-9, 2007.

French, J., Payo, A., Murray, B., Orford, J., Eliot, M., and Cowell, P.: Appropriate complexity for the prediction of coastal and estuarine geomorphic behaviour at decadal to centennial scales, Geomorphology, 256, 3-16, https://doi.org/10.1016/j.geomorph.2015.10.005, 2015.

Gelfenbaum, G. and Kaminsky, G.: Large-scale coastal change in the Columbia River littoral cell: An overview, Mar. Geol., 273, 1-10, https://doi.org/10.1016/j.margeo.2010.02.007, 2010.

Hallermeier, R.: Uses for a Calculated Limit Depth to Beach Erosion, Coast. Eng., 1493-1512, https://doi.org/10.1061/9780872621909.090, 1978.

Hanson, H.: GENESIS: a generalized shoreline change numerical model, J. Coast. Res., 5, 1-27, 1989.

Hanson, H. and Kraus, N.: GENESIS: Generalized Model for Simulating Shoreline Change. Report 1. Technical Reference, No. CERC-TR-89-19-1, Coastal Engineering Research Center, Vicksburg, MS, 1989.

Hurst, M., Barkwith, A., Thomas, C., and Ellis, M.: Vector-based one-line model for shoreline evolution: application to explore wave-climate control on bay morphology, in: AGU Fall Meeting Abstracts, San Franciso, 15-19 December 2014.

Komar, P. D., Lanfredi, N., Baba, M., Dean, R. G., Dyer, K., Healy, T., Ibe, A. C., Terwindt, J. H. J., and Thom, B. G.: The response of beaches to sea-level changes - a review of predictive models, J. Coast. Res., 7, 895-921, 1991.

Leach, C.: CEM2D Source Code, Zenodo [code], https://doi.org/10.5281/zenodo.3341888, 2019.

Leach, C., Coulthard, T., Barkwith, A., Parsons, D., and Manson, S.: CEM2D_Dataset, Zenodo [data set], https://doi.org/10.5281/zenodo.5242895, 2021.

Lesser, G., Roelvink, J., van Kester, J., and Stelling, G.: Development and validation of a three-dimensional morphological model, Coast. Eng., 51, 883-915, https://doi.org/10.1016/j.coastaleng.2004.07.014, 2004.

Lowe, J. A., Howard, T. P., Pardaens, A., Tinker, J., Holt, J., Wakelin, S., Milne, G., Leake, J., Wolf, J., Horsburgh, K., and Reeder, T.: UK Climate Projections science report: Marine and coastal projections, Exeter, UK 2009.

McLean, R. and Kirk, R.: Relationships between grain size, size-sorting, and foreshore slope on mixed sand - shingle beaches, New Zeal. J. Geol. Geop., 12, 138-155, https://doi.org/10.1080/00288306.1969.10420231, 1969.

Morris, M.: Factorial sampling plans for preliminary computational experiments, Technometrics, 33, 161-174, https://doi.org/10.1080/00401706.1991.10484804, 1991.

Murray, B.: Reducing model complexity for explanation and prediction, Geomorphology, 90, 178-191, https://doi.org/10.1016/j.geomorph.2006.10.020, 2007.

Nam, P., Larson, M., Hanson, H., and Hoan, Le X.: A numerical model of nearshore waves, currents, and sediment transport, Coast. Eng., 56, 1084-1096, https://doi.org/10.1016/j.coastaleng.2009.06.007, 2009.

Nicholls, R., Bradbury, A., Burningham, H., Dix, J., Ellis, M., French, J., Hall, J., Karunarathna, H., Lawn, J., Pan, S., Reeve, D., Rogers, B., Souza, A., Stansby, P., Sutherland, J., Tar- rant, O., Walkden, M., and Whitehouse, R.: iCOASST - Integrating Coastal Sediment Systems, Coast. Eng. Proc., 1, 100, https://doi.org/10.9753/icce.v33.sediment.100, 2012.

Nicholls, R., Birkemeier, W., and Hallermeier, R.: Application of the depth of closure concept, Proceedings of the Coastal Engineering Conference, 4, 3874-3887, https://doi.org/10.9753/icce.v25, 1997.

Park, J.-Y. and Wells, J.: Longshore Transport at Cape Lookout, North Carolina: Shoal Evolution and the Regional Sediment Budget, J. Coast. Res., 211, 1-17, https://doi.org/10.2112/02051.1, 2005.

Pinet, P.: Invitation to Oceanography, Jones \& Bartlett Publishers, 2011.

Robinet, A., Idier, D., Castelle, B., and Marieu, V.: A reducedcomplexity shoreline change model combining longshore and cross-shore processes: The LX-Shore model, Environ. Model. Softw., 109, 1-16, https://doi.org/10.1016/j.envsoft.2018.08.010, 2018.

Shaw, J., Fader, G. B., and Taylor, R. B.: Submerged early Holocene coastal and terrestrial landforms on the inner shelves of Atlantic Canada, Quatern. Int., 206, 24-34, https://doi.org/10.1016/j.quaint.2008.07.017, 2009.

Skinner, C. J., Coulthard, T. J., Schwanghart, W., Van De Wiel, M. J., and Hancock, G.: Global sensitivity analysis of parameter uncertainty in landscape evolution models, Geosci. Model Dev., 11, 4873-4888, https://doi.org/10.5194/gmd-11-4873-2018, 2018.

Stive, M. and de Vriend, H.: Modelling shoreface profile evolution, Mar. Geol., 126, 235-248, https://doi.org/10.1016/00253227(95)00080-I, 1995.

Thomas, C. W., Murray, A. B., Ashton, A. D., Hurst, M. D., Barkwith, A. K. A. P., and Ellis, M. A.: Complex coastlines responding to climate change: do shoreline shapes reflect present forcing or "remember" the distant past?, Earth Surf. Dynam., 4, 871-884, https://doi.org/10.5194/esurf-4-871-2016, 2016.

Tucker, G. and Slingerland, R.: Erosional dynamics, flexural isostasy, and long-lived escarpments: A numerical modeling study, J. Geophys. Res.-Sol. Ea., 99, 12229-12243, https://doi.org/10.1029/94JB00320, 1994.

Wainwright, J. and Mulligan, M.: Environmental Modelling: Finding Simplicity in Complexity, Wiley-Blackwell, 2002.

Warren, I. and Bach, H.: MIKE 21: A Modelling System for Estuaries, Coastal Waters and Seas, Environ. Softw., 7, 229-240, https://doi.org/10.1016/0266-9838(92)90006-P, 1992.

Willgoose, G., Bras, R., and Rodriguez-Iturbe, I.: Results from a new model of river basin evolution', Earth Surf. Process. Land., 16, 237-254, https://doi.org/10.1002/esp.3290160305, 1991.

Wong, P., Losada, I., Gattuso, J., Hinkel, J., Khattabi, A., McInnes, K., Saito, Y., Sallenger, A., Nicholls, R., Santos, F., and Amez, S.: Coastal systems and low-lying areas, in: Climate Change 2014 Impacts, Adaptation and Vulnerability: Part A: Global and Sectoral Aspects, Contribution of Working Group II to the Fifth Assessment Report of the Intergovernmental Panel on Climate Change, edited by: Field, C. B., Barros, V. R., Dokken, D. J., Mach, K. J., Mastrandrea, M. D., Bilir, T. E., Chatterjee, M., Ebi, K. L., Estrada, Y. O., Genova, R. C., Girma, B., Kissel, E. S., Levy, A. N., MacCracken, S., Mastrandrea, P. R., and White, L. L., Cambridge University Press, Cambridge, UK, New York, NY, USA, 361-409, 2014. 
van Maanen, B., Barkwith, A., Bonaldo, D., Burningham, H., Murray, B., Payo, A., Sutherland, J., Thornhill, G., Townend, I., van der Wegen, M., and Walkden, M.: Simulating mesoscale coastal evolution for decadal coastal management: A new framework integrating multiple, complementary modelling approaches, Geomorphology, 256, 68-80, https://doi.org/10.1016/j.geomorph.2015.10.026, 2016.

Vitousek, S., Barnard, P. L., Limber, P., Erikson, L., and Cole, B.: A model integrating longshore and cross-shore processes for predicting long-term shoreline response to climate change, J. Geophys. Res.-Earth Surf., 122, 782-806, https://doi.org/10.1002/2016JF004065, 2017.
Wright, L. and Short, A.: Morphodynamic variability of surf zones and beaches: A synthesis, Mar. Geol., 56, 93-118, https://doi.org/10.1016/0025-3227(84)90008-2, 1984.

Ziliani, L., Surian, N., Coulthard, T., and Tarantola, S.: Reduced-complexity modeling of braided rivers: Assessing model performance by sensitivity analysis, calibration, and validation, J. Geophys. Res.-Earth Surf., 118, 2243-2262, https://doi.org/10.1002/jgrf.20154, 2013. 